\title{
Human Beta Defensins 1, 2 and 3 Produced by Amniochorion Membranes Is Similar in Term and Preterm Delivery
}

\author{
Nathália Mayumi Noda-Nicolau' ${ }^{1}$, Jossimara Polettini², Camila Marconi ${ }^{3}$, José Carlos Peraçoli, \\ Hélio Amante Miot ${ }^{5}$, Márcia Guimarães da Silva ${ }^{1}$
}

\footnotetext{
${ }^{1}$ Department of Pathology, Botucatu Medical School, UNESP_Universidade Estadual Paulista, São Paulo, Brazil

${ }^{2}$ The University of Western São Paulo (UNOESTE), Presidente Prudente, Brazil

${ }^{3}$ Department of Basic Pathology, Setor de Ciências Biológicas, UFPR-Universidade Federal do Paraná, Curitiba, Brazil

${ }^{4}$ Department of Gynecology and Obstetrics, Botucatu Medical School, UNESP-Universidade Estadual Paulista,

São Paulo, Brazil

${ }^{5}$ Department of Dermatology, Botucatu Medical School, UNESP_Universidade Estadual Paulista, São Paulo, Brazil Email: nathaliamnicolau@gmail.com, jossimarap@yahoo.com.br, marconi.cml@gmail.com, peracoli@fmb.unesp.br, heliomiot@fmb.unesp.br, mgsilva@fmb.unesp.br
}

How to cite this paper: Noda-Nicolau, N.M., Polettini, J., Marconi, C., Peraçoli, J.C., Miot, H.A. and da Silva, M.G. (2017) Human Beta Defensins 1, 2 and 3 Produced by Amniochorion Membranes Is Similar in Term and Preterm Delivery. Open Journal of Obstetrics and Gynecology, 7, 846-857. https://doi.org/10.4236/ojog.2017.78085

Received: July 1, 2017

Accepted: July 30, 2017

Published: August 2, 2017

Copyright $\odot 2017$ by authors and Scientific Research Publishing Inc. This work is licensed under the Creative Commons Attribution International License (CC BY 4.0).

http://creativecommons.org/licenses/by/4.0/

\section{c) (i) Open Access}

\begin{abstract}
Amniochorion membranes were collected from 25 pregnant women at preterm labor, in the presence or not of Preterm Premature Rupture of Membranes (PPROM) and 27 pregnant women at term in the presence at labor, in order to quantify the expression and to evaluate the immunoreactivity of human beta defensins (HBD)1, HBD2, HBD3 and HBD4 in amniochorion membranes from pregnancies complicated by spontaneous prematurity. The HBDs were evaluated by immunohistochemistry, real time quantitative PCR and ELISA. Statistical analyses were performed using Chi-squared and Mann Whitney tests. There was no significant difference in HBDs expression between study and control groups: HBD1 $(\mathrm{Md}=0.62(0.0-105.0)$ vs $\mathrm{Md}=0.80$ (0.02 - 25.0); $\mathrm{p}=0.85)$, HBD2 ( $\mathrm{Md}=0.17(0.0-5.2)$ vs $\mathrm{Md}=0.0(0.0-43.2) ; \mathrm{p}$ $=0.16), \mathrm{HBD} 3(\mathrm{Md}=0.11(0.0-140.5)$ vs $\mathrm{Md}=0.06(0.0-972.1) ; \mathrm{p}=0.91)$. Also, HBD1, HBD2 and HBD3 protein expression was not significant different between the groups: HBD1 $(1.32 \mathrm{pg} / \mathrm{mL}(0.0-1.85)$ vs $1.08 \mathrm{pg} / \mathrm{mL}(0.04-$ $2.22) ; \mathrm{p}=0.67), \mathrm{HBD} 2(0.00 \mathrm{pg} / \mathrm{mL}(0.0-1.74)$ vs $0.02 \mathrm{pg} / \mathrm{mL}(0.0-1.24) ; \mathrm{p}=$ $0.69)$, HBD3 (0.04 pg/mL (0.0 - 1.05) vs $0.09 \mathrm{pg} / \mathrm{mL}(0.0-1.05) ; \mathrm{p}=0.63)$. The immunoreactivity of HBD1, HBD2 and HBD3 was observed in amnion, chorion and decidua cells from preterm and term pregnancies. Amniochorion membranes are sources of HBD1, HBD2 and HBD3 and their expressions are similar in term and preterm pregnancies.
\end{abstract}




\section{Keywords}

Preterm Birth, Amniochorion Membranes, Human Beta Defensins

\section{Introduction}

Preterm birth (PTB) affects $11.1 \%$ of all pregnancies worldwide [1], in which $70 \%$ are spontaneous [2] and present multifactorial etiology, as infection or inflammation, uteroplacental ischaemia or haemorrhage, uterine overdistension or stress [3] and maternal risk factors as previous PTB [4]. However, there are abundant evidences that the infection/inflammation is strongly related to this syndrome, mostly linked to ascending microorganisms from the lower genital tract [5] [6], in which is present in nearly $50 \%$ of PTB and $70 \%$ of preterm premature rupture of membranes (pPROM) [7].

The infection of the amniotic cavity triggers the immune response and lead to an inflammation with different production of cytokines and Toll-Like Receptors (TLR) expression modifying the normal scenario of gestation and culminating to the PTB [8]. Thus, in the presence of microbial invasion of the amniotic cavity (MIAC) the innate immune response has an important role to eliminate the pathogens and re-establish the normal environment of the amniotic cavity, in this sense, the natural antimicrobial peptides are important since they provide protection against microorganism's infection [9] [10].

Among natural antimicrobial peptides, human beta defensins (HBDs) are important contributors to host immunity [9]. HBDs are small cationic peptides classified inside the higher group named defensins and have been described four types in detail until now, HBD1, HBD2, HBD3 and HBD4 [11]. The expression and release these peptides depend on the defensins and cell type and stimuli (cytokines/chemokines and microorganisms) being constitutive or inducible regulated. HBD1 is more frequently to be constitutively produced, but its production could be inducible as well [12], being able to control the microbial flora on epithelial surfaces even without inflammatory markers [13] [14] [15]. On the other hand, HBD2 is highly inducible in the presence of IL-1 $\beta$, IL-8 [15], [16], tumor necrosis factor-alpha (TNF- $\alpha$ ), lipopolysaccharide (LPS), gram-negative and gram-positive bacteria and yeast [13] [17] [18] [19] [20], while HBD3 is inducible by TNF- $\alpha$, heat-inactivated bacteria [21] and interferon- $\gamma$ [22].

Additionally, HBDs are mainly effective against gram-negative and grampositive bacteria and yeast, but this microbial activity against bacteria is not the same for these defensins, in which HBD1 and 2 are predominantly against gramnegative bacteria and yeasts [21] [23], HBD4 is effective against gram-negative and gram-positive bacteria [24] and HBD3 is active for all the cited microorganisms [21]. The antimicrobial activity is explained by the ability to the HBD2, for example, to inhibit the LPS action and block the inflammation by the LPS-induced TNF- $\alpha$ production [25]. The similar way HBD3 is able to neutralize LPS 
[26], besides an in vitro study with S. aureus showed that its action is in the plasma membrane since it has the capability to cause morphological changes in the peripheral cell wall [21]. Moreover, HBD3 has a broad spectrum of antimicrobial activity against several pathogenic bacteria at low concentrations and independent of the sodium concentration [21].

In gestational scenarium, HBDs were described in fetal membranes, placenta and amniotic fluid [27] [28] [29]. HBD1-3 was expressed in amnion, chorion and decidual cells from term and preterm pregnancies [27] [28]. The presence of HBD2 in the amniotic fluid was associated with pPROM [29] and with intraamniotic inflammation in patients with PTL without microbial invasion [30]. In an in vitro study, amnion cells were able to induce $\mathrm{HBD} 3$ production in the presence of LPS [31] and HBD2 in response to Group B Streptococcus [32]. Additionally, chorioamniotic membranes in vitro were able to produce HBD 1 - 3 after stimulation with Gardnerella vaginalis [33] and Streptococcus agalactiae [34].

Therefore, considering that inflammatory events in the amniotic cavity could be pronounced in the preterm pregnancy and that fetal membranes have inhibitory effect in the bacteria growth, partially, by human beta defensins production, we aimed to quantify the protein and gene expression and to evaluate the immunoreactivity of HBD1, HBD2, HBD3 and HBD4 in amniochorion membranes from pregnancies complicated by spontaneous prematurity.

\section{Material and Methods}

\subsection{Study Design and Participants}

This is a prospective study with 52 pregnant women seen at the Obstetric Unit from Botucatu Medical School, São Paulo State University. The sample calculation was estimated considering the mean values of HDB1, HDB2, HBD3 and HDB4 expression in chorioamniotic membranes of preterm and term gestations in a pilot study. Correcting for the effects of $\alpha(5 \%)$ and $\beta$ (20\%) errors attributed to the study, a minimum required sample size was 50 chorioamniotic membranes. The fetal membranes were collected during January 2008 until December 2012 and the groups were composed by 25 fetal membranes from pregnant women in PTL with intact membranes or pPROM ending in PTB (PTB group) and 27 fetal membranes from pregnant women at term (Term group). Preterm pregnant women were not eligible if they presented multiple pregnancies, diabetes, hypertension, fetal anomalies, placental abruption, placenta previa, intrauterine growth restriction and urinary tract infection. Term pregnant women were eligible if they were having a singleton term and an uneventful pregnancy, defined as being free from any chronic or gestational medical conditions (including any condition that would require pregnant women bed rest for any reasons), intact membranes, and obstetric history with no previous complications. This study was approved by the Human Research Ethics Committee (UNESP) under protocol 189/2012 and all the women enrolled signed a term of written consent to participate. 
Gestational age was established by the last menstruation and/or from the ultrasound until 20 weeks. Pregnancies complicated by pPROM was confirmed by the clinic history and confirmation of amniotic fluid in the vaginal cavity or when it was not possible, we performed assay in the cervicovaginal fluid as positive nitrazine paper test, positive fern test and search for fetal cells. The diagnosis of PTL was confirmed by the presence of regular uterine contractions every ten minutes or less and cervical effacement equal or superior to $50 \%$ and/or cervical dilatation of at least $2 \mathrm{~cm}$ at less than 37 weeks of gestation. Both, pPROM and PTL, were defined according to the Brazilian Ministry of Health guidelines (http://bvsms.saude.gov.br/bvs/publicacoes/manual_pre_natal_puerperio_3ed.pdf).

After delivery, fragments of fetal membranes were frozen in liquid nitrogen and stored at $-80^{\circ} \mathrm{C}$ until the RNA and protein extraction and the remainder was fixed in $10 \%$ formalin and embedded in paraffin for histopathologic and immunohistochemistry analysis. The histologic chorioamnionitis status was diagnosed according to Yoon et al. [35].

\subsection{Genic Expression Evaluation}

To analyze the genic expression of HBD1, HBD2, HBD3 and HBD4, we performed the RNA extraction with frozen fragments of fetal membranes using RNAspin Mini RNA Isolation Kit (GE Healthcare). Then, assessment of RNA integrity was performed using Agilent RNA 6000 Nano kit with Agilent 2100 Bioanalyzer, and samples were submitted to reverse transcription using the High-Capacity cDNA Archive kit according to the manufactorer's instructions (Applied Biosystems). Then, the real time quantitative PCR was performed with TaqMan-validated primers and TaqMan MGB probes to the studied human beta defensins (Hs00174765_m1 (HBD1), Hs00175474_m1 (HBD2), Hs00218678_m1 (HBD3) and Hs00414476_m1 (HBD4) and housekeeping gene TBP

(Hs99999910_m1) using Line Gene K (Bioer $\left.{ }^{\circledR}\right)$. The threshold cycle number (CT) was used to determine relative HBD mRNA expression, using the ddCT method and the mean of CT from a pool of samples from control group was used as calibrator.

\subsection{Immunohistochemical Analysis}

We used Mach 4 Universal HRP Polymer Kit with DAB (Biocare Medical), then histologic sections with six micron-thick of fetal membranes embedded in paraffin blocks were mounted on slides, dried at $37^{\circ} \mathrm{C}$ for 24 hours and subjected to deparaffinization and to antigen-retrieval by boiling in Trilogy $^{\text {tm }}$ solution (Cell Marque, Hot Springs, AR) for 30 minutes. The blocking endogenous peroxidase activity was performed using hydrogen peroxide $3 \%$ diluted in water two times during 30 minutes. The primary antibodies anti-HBD1 (1:500), HBD2 (1:250), HBD3(1:25) and HBD4 (no diluted) (Abcam) were diluted in bovine albumin $1 \%$ solution, $0.1 \%$ sodium azide in PBS pH 7.4 and incubated overnight in a humid chamber. Finally, sections were counterstained with Harris hematoxylin 
and for the negative control we removed the primary antibodies from the protocol. The positive mark was detected with a brown cytoplasmic pattern.

\subsection{Protein Expression Evaluation}

In order to quantify the protein expression of beta defensins using ELISA methodology, fragments of frozen amniochorion membranes samples were lysed in a RIPA buffer [PBS, 1\% (v/v) Nonidet P-40, 0.5\% (w/v) sodium deoxycholate, $0.1 \%$ sodium dodecyl sulfate (SDS) and protease/phosphatase inhibitor (10 $\mu \mathrm{L} / \mathrm{mL}$, HaltTM Protease and Phosphatase Inhibitor Cocktail, EDTA-Free, Thermo Scientific)]. The protein concentration in all lysate was determined using PierceTM BCA Protein Assay Kit. Then, we evaluated the protein expression using Peprotech specific kits to quantify HBD1 (900-M202), HBD2 (900-M172), HBD3 (900-M210) and HBD4 (900-M435) following the manufacture's instruction. The measured was performed in an automatic ELISA reader (Epoch-Bio Tek).

\subsection{Statistical Analysis}

Data on maternal age, gestational age at delivery, newborn weight, relative quantification of gene expression and protein expression in the studied groups were compared with Mann-Whitney test. Data on marital status, race, paritity, and frequency of previous pregnancy complication were compared using $\mathrm{x}^{2}$ test. Correlation between human beta defensins levels and advancing gestation was analyzed using Spearman's test. A p value $<0.05$ was considered to be statistically significant and the software used was SigmaStat version 3.1 (Jandel Corporation).

\section{Results}

The sociodemographic and obstetric variables of the all pregnant women included in this study are presented in Table 1. Due to the study design, statistically significant difference was observed for newborn weight $(p=0.001)$ and gestational age at delivery $(\mathrm{p}=0.001)$ with a higher value in the control group compared to the premature group. Obstetric history, including parity and previous pregnancy complication, was similar between the groups.

All fetal membranes from control group showed microscopically a normal histologic pattern. In the premature group the incidence of histologic chorioamnionitis was $44 \%(11 / 25)$.

The results obtained in this study showed that human beta defensins levels did not correlate positively with advancing gestation (Figure 1).

The relative quantification of gene expression of HBD1, HBD2 and HBD3 by fetal membranes is presented in the Table 2 and no statistically significant difference between premature and control group was observed (HBD1 $p=0.88$; HBD2 $p=0.28$; HBD3 $p=0.87$ ). Additionally, no statistically difference was detected regarding the histologic chorioamnionitis status $(\mathrm{HBD} 1 \mathrm{p}=0.12$; HBD2 $\mathrm{p}$ 
$=0.17 ; \operatorname{HBD} 3 \mathrm{p}=0.80)$ or the PPROM presence $(\mathrm{HBD} 1 \mathrm{p}=0.72 ; \mathrm{HBD} 2 \mathrm{p}=$ 0.52; HBD3 $\mathrm{p}=0.09$ ) (Table 2). No gene expression of HBD4 was detected.

The HBD1, HBD2 and HBD3 protein expression was not significant different

Table 1. Demographic and obstetric variables of the pregnant women included in the study.

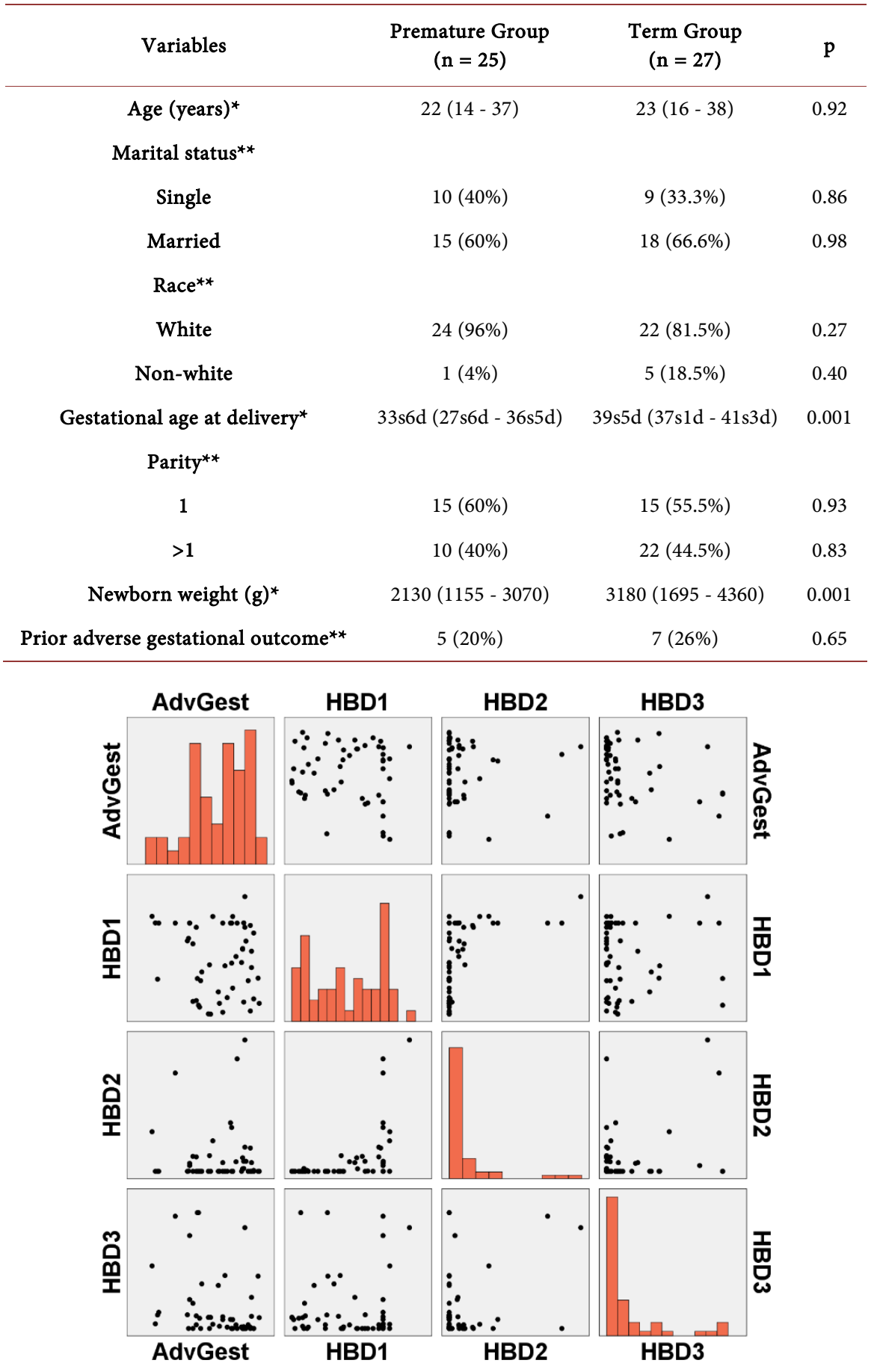

Figure 1. Correlation matrix among human beta defensins levels and gestational age. The Spearman's rho were $<0.1$ between advancing gestation versus HBD1 $(-0.121)$, HBD2 (0.07) and HBD3 (-0.389). 
Table 2. Relative quantification of gene expression of HBD1, HBD2 and HBD3 in the fetal membranes.

\begin{tabular}{|c|c|c|c|c|c|c|c|c|c|}
\hline & $\begin{array}{l}\text { Premature } \\
\text { group }\end{array}$ & Term group & $\mathrm{p}$ & $\begin{array}{l}\text { Premature with } \\
\text { chorioamnionitis }\end{array}$ & $\begin{array}{l}\text { Premature without } \\
\text { chorioamnionitis }\end{array}$ & $\mathrm{p}$ & pPROM & PTL & $\mathrm{p}$ \\
\hline HBD1 & $\begin{array}{c}0.63 \text {-fold } \\
(0.0-105.1)\end{array}$ & $\begin{array}{c}0.94 \text {-fold } \\
(0.0-25.0)\end{array}$ & 0.88 & $\begin{array}{c}1.14 \text {-fold } \\
(0.02-105.1)\end{array}$ & $\begin{array}{c}0.37 \text {-fold } \\
(0.0-10.74)\end{array}$ & 0.12 & $\begin{array}{c}0.88 \text {-fold } \\
(0.02-67.4)\end{array}$ & $\begin{array}{c}0.62 \text {-fold } \\
(0.0-105.1)\end{array}$ & 0.72 \\
\hline HBD2 & $\begin{array}{c}0.17 \text {-fold } \\
(0.0-141.0)\end{array}$ & $\begin{array}{c}0.06 \text {-fold } \\
(0.0-972.1)\end{array}$ & 0.28 & $\begin{array}{c}0.28 \text {-fold } \\
(0.0-141.0)\end{array}$ & $\begin{array}{c}0.09 \text {-fold } \\
(0.0-58.3)\end{array}$ & 0.17 & $\begin{array}{c}0.26 \text {-fold } \\
(0.0-140.6)\end{array}$ & $\begin{array}{c}0.09 \text {-fold } \\
(0.0-141.0)\end{array}$ & 0.52 \\
\hline HBD3 & $\begin{array}{c}0.06-\text { fold } \\
(0.0-5.19)\end{array}$ & $\begin{array}{c}0.12 \text {-fold } \\
(0.0-43.3)\end{array}$ & 0.87 & $\begin{array}{l}0.04 \text {-fold } \\
(0.0-5.2)\end{array}$ & $\begin{array}{l}0.19 \text {-fold } \\
(0.0-1.6)\end{array}$ & 0.80 & $\begin{array}{l}0.18 \text {-fold } \\
(0.0-5.2)\end{array}$ & $\begin{array}{l}0.02 \text {-fold } \\
(0.0-1.3)\end{array}$ & 0.09 \\
\hline
\end{tabular}

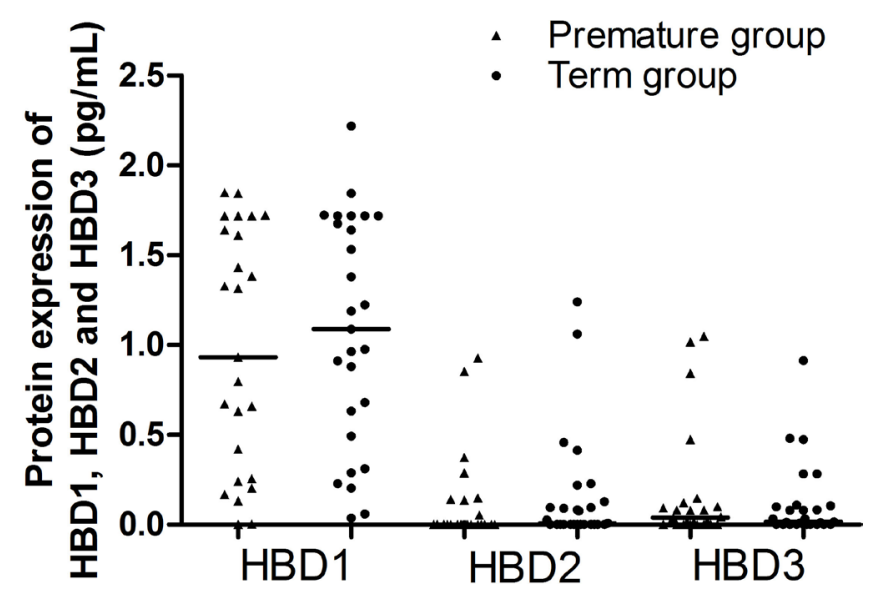

Figure 2. Protein expression of HBD1, HBD2 and HBD3 in the fetal membranes included in this study regarding the gestational age. Mann-Whitney test, $\mathrm{p}>0.05$.

between the premature and control groups: HBD1 $(0.93 \mathrm{pg} / \mathrm{mL}(0.0-1.85)$ vs $1.08 \mathrm{pg} / \mathrm{mL}(0.04-2.22) ; \mathrm{p}=0.60), \mathrm{HBD} 2(0.00 \mathrm{pg} / \mathrm{mL}(0.0-0.93) \mathrm{vs} 0.01 \mathrm{pg} / \mathrm{mL}$ (0.0 - 1.24); $\mathrm{p}=0.35)$, HBD3 (0.04 pg/mL $(0.0$ - 1.05) vs $0.02 \mathrm{pg} / \mathrm{mL}(0.0-0.91)$; $\mathrm{p}=0.66$ ) (Figure 2).

All fetal membranes from control and premature group presented immunostaining for HBD1, HBD2 and HBD3 in the amniotic, chorionic and decidual cells (Figure 3). No immunostaining was observed for HBD4.

\section{Discussion}

The present study demonstrated that preterm and term fetal membranes produce HBD1, HBD2 and HBD3 and this expression is not modulated by prematurity, PPROM or chorioamnionitis. The infection and inflammation of the amniotic cavity are important factor leading to the preterm labor [36], and in this scenario, HBDs as a part of the first line of the immune response have a great role in order to intercept the infection in the initial phase and inhibit the inflammatory cascade activation. Moreover HBDs are able to active the adaptive immune system by different ways, stimulating immune cell migration by CCR6 [37] [38], CCR2 [39] and TLRs [40] [41], promoting the release of proinflammatory cytokines and recruiting antigen-presenting cells [11].

However, our results contradict our hyphotesis that preterm fetal membranes 


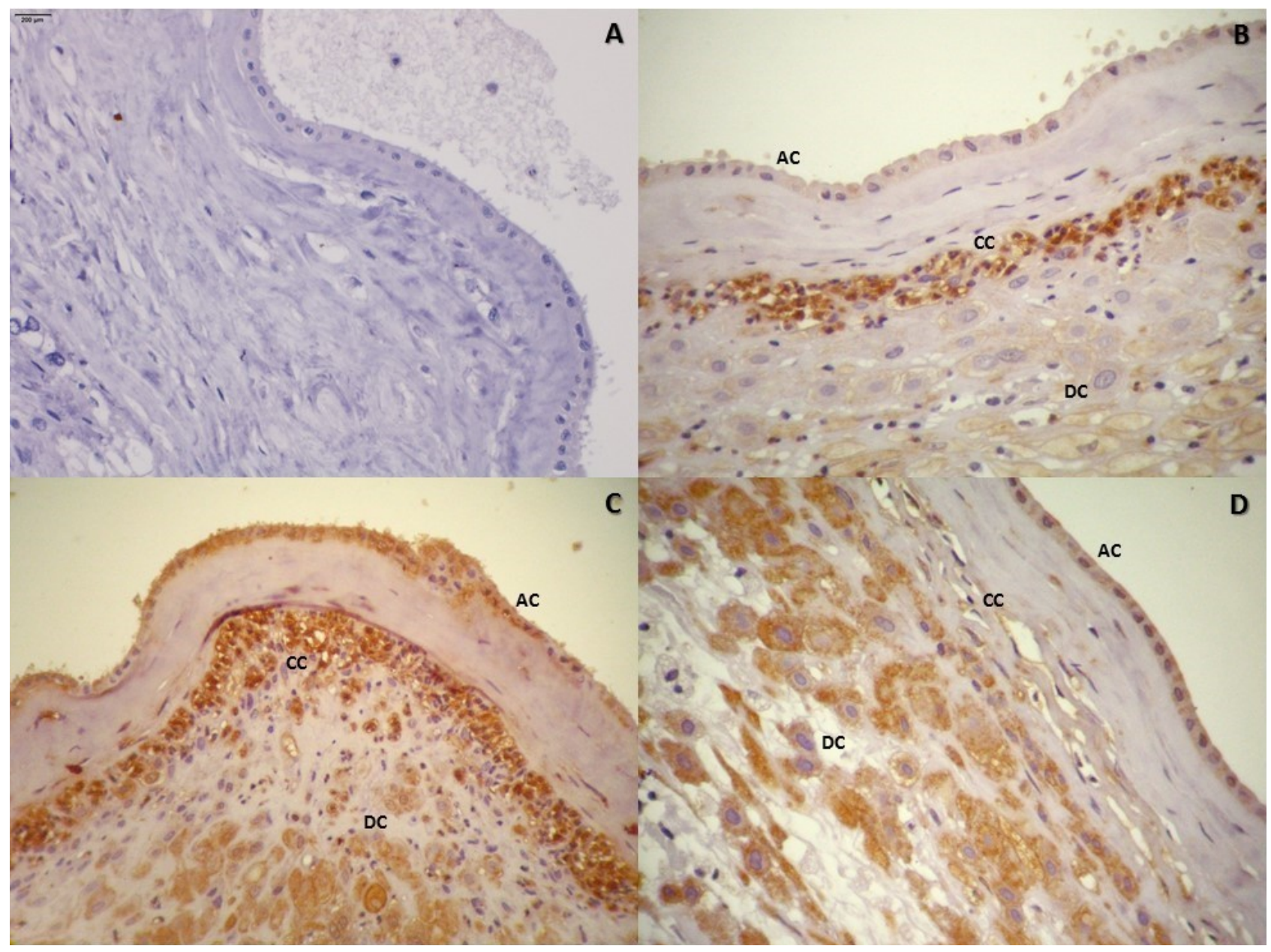

Figure 3. Immunohistochemical staining for HBD expression in amniochorionic membranes and decidua. (A) amniochorion section and decidua with no staining (negative control), 400x; (B) HBD1 in amniotic cells (AC), chorionic (CC) and decidual cells (DC), 400×; C) HBD2 in amniotic cells (AC), chorionic (CC) and decidual cells (DC), 200×; D) HBD3 in amniotic cells (AC), chorionic (CC) and decidual cells (DC), 400x. Sections were counterstained with Harris hematoxylin.

express higher concentrations of HBDs. In this sense, previous studies failed to demonstrated association with HBD1 and PTL or PPROM [42] and HBD3 in the amniotioc fluid in the second trimester and PTL, in the presence or absence of pPROM [29].

One explanation for our results could be the constitution of the studied groups. Although the control group has only term gestation, all patients were in labor, and according to the literature, molecules and receptors involved in the innate immunity are overexpressed in gestational tissues at the moment of the labor [43], in order to increase the host against microbial invasion of the amniotic cavity, since in this moment the cervix is dilated and the amniotic cavity leaves more susceptible to infections. Although Soto et al. [30] did not demonstrate different concentration of HBD2 in women at term regarding the presence or absence of labor, another study described an association between increased $\alpha$-defensins-1-3 in pregnant women in labor at term compared to women not in labor [44], then we suggested that HBDs are also over expressed in the term fetal 
membranes under the labor, thus is not possible determine the real prematurity influence in the expression of studied HBDs. The inclusion of a control group at term without labor will be relevant to clarify this hypothesis.

In relation to the HBD4 production, we could not detected gene and protein expression of this defensin in the fetal membranes, as Stock et al. that failed to demonstrated HBD4 mRNA presence in amniotic cells culture [45].

Regarding to the immunostaining of HBD1, HBD2 and HBD3 in the fetal membranes, our results corroborate with the literature, in which this HBDs were described in the amnion, chorion and decidua from term and preterm fetal membranes [27] [28].

Our results confirm that the fetal membranes are not only mechanical protection but are immunological barrier and HBD1, HBD2 and HBD3 expression is similar in term and preterm pregnancies.

\section{References}

[1] Blencowe, H., Cousens, S., Oestergaard, M.Z., Chou, D., Moller, A.B., Narwal, R., Adler, A., Vera Garcia, C., Rohde, S., Say, L. and Lawn, J.E. (2012) National, Regional, and Worldwide Estimates of Preterm Birth Rates in the Year 2010 with Time Trends since 1990 for Selected Countries: A Systematic Analysis and Implications. The Lancet, 379, 2162-2172.

[2] Goldenberg, R.L., Culhane, J.F., Iams, J.D. and Romero, R. (2008) Epidemiology and Causes of Preterm Birth. The Lancet, 371, 75-84.

[3] Romero, R., Espinoza, J., Kusanovic, J.P., Gotsch, F., Hassan, S., Erez, O., Chaiworapongsa, T. and Mazor, M. (2006) The Preterm Parturition Syndrome. BJOG: An International Journal of Obstetrics \& Gynaecology, 113, 17-42. https://doi.org/10.1111/j.1471-0528.2006.01120.x

[4] Rubens, C.E., Sadovsky, Y., Muglia, L., Gravett, M.G., Lackritz, E. and Gravett, C. (2014) Prevention of Preterm Birth: Harnessing Science to Address the Global Epidemic. Science Translational Medicine, 6, $262 \mathrm{sr} 5$.

[5] Romero, R., Espinoza, J., Gonçalves, L.F., Kusanovic, J.P., Friel, L.A. and Nien, J.K. (2006) Inflammation in Preterm and Term Labour and Delivery. Seminars in Fetal and Neonatal Medicine, 11, 317-326.

[6] Donders, G.G., Van Calsteren, K., Bellen, G., Reybrouck, R., Van Den Bosch, T., Riphagen, I. and Van Lierde, S. (2009) Predictive Value for Preterm Birth of Abnormal Vaginal Flora, Bacterial Vaginosis and Aerobic Vaginitis during the First Trimester of Pregnancy. BJOG: An International Journal of Obstetrics \& Gynaecology, 116, 1315-1324. https://doi.org/10.1111/j.1471-0528.2009.02237.x

[7] Menon, R. (2014) Oxidative Stress Damage as a Detrimental Factor in Preterm Birth Pathology. Frontiers in Immunology, 5, 1-14. https://doi.org/10.3389/fimmu.2014.00567

[8] Menon, R., Peltier, M.R., Eckardt, J. and Fortunato, S.J. (2009) Diversity in Cytokine Response to Bacteria Associated with Preterm Birth by Fetal Membranes. American Journal of Obstetrics \& Gynecology, 201, 306.e1-6.

[9] Ganz, T. (2003) The Role of Antimicrobial Peptides in Innate Immunity. Integrative and Comparative Biology, 43, 300-304. https://doi.org/10.1093/icb/43.2.300

[10] Mattar, E.H., Almehdar, H.A., Yacoub, H.A., Uversky, V.N. and Redwan, E.M. (2016) Antimicrobial Potentials and Structural Disorder of Human and Animal 
Defensins. Cytokine \& Growth Factor Reviews, 28, 95-111.

[11] Suarez-Carmona, M., Hubert, P., Delvenne, P. and Herfs, M. (2015) Defensins: "Simple" Antimicrobial Peptides or Broad-Spectrum Molecules? Cytokine \& Growth Factor Reviews, 26, 361-370.

[12] Joly, S., Organ, C.C., Johnson, G.K., McCray, P.B. and Guthmiller, J.M. (2005) Correlation between $\beta$-Defensin Expression and Induction Profiles in Gingival Keratinocytes. Molecular Immunology, 42, 1073-1084.

[13] Zhao, C., Wang, I. and Lehrer, R.I. (1996) Widespread Expression of Beta-Defensin hBD-1 in Human Secretory Gland and Epithelial Cells. FEBS Letters, 396, 319-322.

[14] McCray, P.B.J. and Bentley, L. (1997) Human Airway Epithelia Express a Beta-Defensin. American Journal of Respiratory Cell and Molecular Biology, 16, 343 349. https://doi.org/10.1165/ajrcmb.16.3.9070620

[15] Singh, P.K., Jia, H.P., Wiles, K., Hesselberth, J., Liu, L., Conway, B.A., Greenberg, E.P., Valore, E.V., Welsh, M.J., Ganz, T., Tack, B.F. and McCray, P.B. (1998) Production of Beta-Defensins by Human Airway Epithelia. Proceedings of the National Academy of Sciences of the United States, 95, 14961-14966.

https://doi.org/10.1073/pnas.95.25.14961

[16] Harder, J., Meyer-Hoffert, U., Teran, L.M., Schwichtenberg, L., Bartels, J., Maune, S. and Schröder, J.M. (2000) Mucoid Pseudomonas aeruginosa, TNF- $\alpha$, and IL-1 $\beta$, but Not IL-6, Induce Human $\beta$-Defensin-2 in Respiratory Epithelia. American Journal of Respiratory Cell and Molecular Biology, 22, 714-721.

[17] Huttner, K.M. and Bevins, C.L. (1999) Antimicrobial Peptides as Mediators of Epithelial Host Defense. Pediatric Research, 45, 785-794.

https://doi.org/10.1203/00006450-199906000-00001

[18] Mathews, M., Jia, H.P., Guthmiller, J.M., Losh, G., Graham, S., Johnson, G.K., Tack, B.F. and McCray, P.B. (1999) Production of Beta-Defensin Antimicrobial Peptides by the Oral Mucosa and Salivary Glands. Infection and Immunity, 67, 2740-2745.

[19] Harder, J., Bartels, J., Christophers, E. and Schröder, J.M. (1997) A Peptide Antibiotic from Human Skin. Nature, 387, 861. https://doi.org/10.1038/43088

[20] Chadebech, P., Goidin, D., Jacquet, C., Viac, J., Schmitt, D. and Staquet, M.J. (2003) Use of Human Reconstructed Epidermis to Analyze the Regulation of Beta-Defensin hBD-1, hBD-2, and hBD-3 Expression in Response to LPS. Cell Biology and Toxicology, 19, 313-324. https://doi.org/10.1023/B:CBTO.0000004975.36521.c8

[21] Harder, J., Bartels, J., Christophers, E. and Schröder, J.M. (2001) Isolation and Characterization of Human $\beta$-Defensin-3, a Novel Human Inducible Peptide Antibiotic. The Journal of Biological Chemistry, 276, 5707-5713. https://doi.org/10.1074/jbc.M008557200

[22] García, J.R.C., Jaumann, F., Schulz, S., Krause, A., Rodríguez-Jiménez, J., Forssmann, U., Adermann, K., Klüver, E., Vogelmeier, C., Becker, D., Hedrich, R., Forssmann, W.G. and Bals, R. (2001) Identification of a Novel, Multifunctional $\beta$-Defensin (Human $\beta$-Defensin 3) with Specific Antimicrobial Activity: Its Interaction with Plasma Membranes of Xenopus oocytes and the Induction of Macrophage Chemoattraction. Cell and Tissue Research, 306, 257-264.

https://doi.org/10.1007/s004410100433

[23] Schroder, J.M. and Harder, J. (1999) Human Beta-Defensin-2. The International Journal of Biochemistry \& Cell Biology, 31, 645-651.

[24] Taylor, K., Barran, P.E. and Dorin, J.R. (2007) Structure-Activity Relantionships in $\beta$-Defensin Peptides. Peptide Science, 90, 1-7. https://doi.org/10.1002/bip.20900

[25] Scott, M.G., Vreugdenhil, A.C.E., Buurman, W.A., Hancock, R.E.W. and Gold, M.R. 
(2000) Cutting Edge: Cationic Antimicrobial Peptides Block the Binding of Lipopolysaccharide (LPS) to LPS Binding Protein. The Journal of Immunology, 164, 549553. https://doi.org/10.4049/jimmunol.164.2.549

[26] Dhople, V., Krukemeyer, A. and Ramamoorthy, A. (2006) The Human Beta-Defensin-3, an Antibacterial Peptide with Multiple Biological Functions. Biochimica et Biophysica Acta (BBA) -Biomembranes, 1758, 1499-1512.

[27] King, A., Paltoo, A., Kelly, R., Sallenave, J., Bocking, A. and Challis, J. (2007) Expression of Natural Antimicrobials by Human Placenta and Fetal Membranes. Placenta, 28, 161-169.

[28] King, A., Kelly, R., Sallenave, J., Bocking, A. and Challis, J. (2007) Innate Immune Defences in the Human Uterus during Pregnancy. Placenta, 28, 1099-1106.

[29] Iavazzo, C., Tassis, K., Gourgiotis, D., Boutsikou, M., Baka, S., Hassiakos, D., Hadjithomas, A., Botsis, D. and Malamitsi-Puchner, A. (2010) The Role of Human Beta Defensins 2 and 3 in the Second Trimester Amniotic Fluid in Predicting Preterm Labor and Premature Rupture of Membranes. Archives of Gynecology and Obstetrics, 281, 793-799. https://doi.org/10.1007/s00404-009-1155-4

[30] Soto, E., Espinoza, J., Nien, J.K., Kusanovic, J.P., Erez, O., Richani, K., Santolaya-Forgas, J. and Romero, R. (2007) Human Beta-Defensin-2: A Natural Antimicrobial Peptide Present in Amniotic Fluid Participates in the Host Response to Microbial Invasion of the Amniotic Cavity. The Journal of Maternal-Fetal \& Neonatal Medicine, 20, 15-22. https://doi.org/10.1080/14767050601036212

[31] Buhimschi, I.A., Jabr, M., Buhimschi, C.S., Petkova, A.P., Weiner, C.P. and Saed, G.M. (2004) The Novel Antimicrobial Peptide $\beta 3$-Defensin Is Produced by the Amnion: A Possible Role of the Fetal Membranes in Innate Immunity of the Amniotic Cavity. American Journal of Obstetrics \& Gynecology, 191, 1678-1687.

[32] Boldenow, E., Hogan, K.A., Chames, M.C., Aronoff, D.M., Xi, C. and Loch-Caruso, R. (2015) Role of Cytokine Signaling in Group B Streptococcus-Stimulated Expression of Human Beta Defensin-2 in Human Extraplacental Membranes. American Journal of Reproductive Immunology, 73, 263-272. https://doi.org/10.1111/aji.12325

[33] Zaga-Clavellina, V., Martha, R.V.M. and Flores-Espinosa, P. (2012) In Vitro Secretion Profile of Pro-Inflammatory Cytokines IL- $1 \beta$, TNF- $\alpha$, IL-6, and of Human Beta-Defensins (HBD)-1, HBD-2, and HBD-3 from Human Chorioamniotic Membranes after Selective Stimulation with Gardnerella vaginalis. American Journal of Reproductive Immunology, 67, 34-43. https://doi.org/10.1111/j.1600-0897.2011.01054.x

[34] Zaga-Clavellina, V., Garcia-Lopez, G. and Flores-Espinosa, P. (2012) Evidence of in Vitro Differential Secretion of Human Beta-Defensins-1, -2, and -3 after Selective Exposure to Streptococcus agalactiae in Human Fetal Membranes. The Journal of Maternal-Fetal \& Neonatal Medicine, 25, 358-363. https://doi.org/10.3109/14767058.2011.578695

[35] Yoon, B., Romero, R., Kim, C., Jun, J., Gomez, R., Choi, J. and Syn, H. (1995) Amniotic Fluid Interleukin-6: A Sensitive Test for Antenatal Diagnosis of Acute Inflammatory Lesions of Preterm Placenta and Prediction of Perinatal Morbidity. American Journal of Obstetrics \& Gynecology, 172, 960-970.

[36] Goldenberg, R.L., Hauth, J.C. and Andrews, W.W. (2000) Intrauterine Infection and Preterm Delivery. The New England Journal of Medicine, 342, 1500-1507. https://doi.org/10.1056/NEJM200005183422007

[37] Yang, D., Chertov, O., Bykovskaia, S.N., Chen, Q., Buffo, M.J., Shogan, J., Ander- 
son, M., Schröder, J.M., Wang, J.M., Howard, O.M. and Oppenheim, J.J. (1999) Beta-Defensins: Linking Innate and Adaptive Immunity through Dendritic and T Cell CCR6. Science, 286, 525-528. https://doi.org/10.1126/science.286.5439.525

[38] Ganz, T. (2003) Defensins: Antimicrobial Peptides of Innate Immunity. Nature Reviews Immunology, 3, 710-720. https://doi.org/10.1038/nri1180

[39] Röhrl, J., Yang, D., Oppenheim, J.J. and Hehlgans, T. (2010) Human Beta-Defensin 2 and 3 and Their Mouse Orthologs Induce Chemotaxis through Interaction with CCR2. The Journal of Immunology, 184, 6688-6694.

https://doi.org/10.4049/jimmunol.0903984

[40] Funderburg, N., Lederman, M.M., Feng, Z., Drage, M.G., Jadlowsky, J., Harding, C.V., Weinberg, A. and Sieg, S.F. (2007) Human-Defensin-3 Activates Professional Antigen-Presenting Cells via Toll-Like Receptors 1 and 2. Proceedings of the National Academy of Sciences of the United States, 104, 18631-18635. https://doi.org/10.1073/pnas.0702130104

[41] Biragyn, A., Ruffini, P., Leifer, C., Klyushnenkova, E., Shakhov, A., Chertov, O., Shirakawa, A., Farber, J., Segal, D., Oppenheim, J. and Kwak, L. (2002) Toll-Like Receptor 4-Dependent Activation of Dendritic Cells by Beta-Defensin 2. Science, 298, 1025-1029. https://doi.org/10.1126/science.1075565

[42] Erez, O., Romero, R., Tarca, A., Chaiworapongsa, T., Kim, Y., Than, N., Vaisbuch, E., Draghici, S. and Tromp, G. (2009) Differential Expression Pattern of Genes Encoding for Anti-Microbial Peptides in the Fetal Membranes of Patients with Spontaneous Preterm Labor and Intact Membranes and Those with Preterm Prelabor Rupture of the Membranes. The Journal of Maternal-Fetal \& Neonatal Medicine, 22, 1103-1115. https://doi.org/10.3109/14767050902994796

[43] Kim, Y.M., Romero, R., Chaiworapongsa, T., Kim, G.J., Kim, M.R., Kuivaniemi, H., Tromp, G., Espinoza, J., Bujold, E., Abrahams, V.M. and Mor, G. (2004) Toll-Like Receptor-2 and -4 in the Chorioamniotic Membranes in Spontaneous Labor at Term and in Preterm Parturition That Are Associated with Chorioamnionitis. American Journal of Obstetrics \& Gynecology, 191, 1346-1355.

[44] Espinoza, J., Chaiworapongsa, T., Romero, R., Edwin, S., Rathnasabapathy, C., Gomez, R., Bujold, E., Camacho, N., Kim, Y., Hassan, S., Blackwell, S., Whitty, J., Berman, S., Redman, M., Yoon, B. and Sorokin, Y. (2003) Antimicrobial Peptides in Amniotic Fluid: Defensins, Calprotectin and Bacterial/Permeability-Increasing Protein in Patients with Microbial Invasion of the Amniotic Cavity, Intra-Amniotic Inflammation, Preterm Labor and Premature Rupture of Membranes. The Journal of Maternal-Fetal \& Neonatal Medicine, 13, 2-21. https://doi.org/10.1080/jmf.13.1.2.21

[45] Stock, S.J., Kelly, R.W., Riley, S.C. and Calder, A.A. (2007) Natural Antimicrobial Production by the Amnion. American Journal of Obstetrics \& Gynecology, 196, 255.e1-255.e6. 
Submit or recommend next manuscript to SCIRP and we will provide best service for you:

Accepting pre-submission inquiries through Email, Facebook, LinkedIn, Twitter, etc. A wide selection of journals (inclusive of 9 subjects, more than 200 journals)

Providing 24-hour high-quality service

User-friendly online submission system

Fair and swift peer-review system

Efficient typesetting and proofreading procedure

Display of the result of downloads and visits, as well as the number of cited articles Maximum dissemination of your research work

Submit your manuscript at: http://papersubmission.scirp.org/

Or contact ojog@scirp.org 